\title{
PELAKSANAAN BELAJAR DARI RUMAH SELAMA COVID-19 PADA ANAK USIA 5-6 TAHUN DI KAMPUNG CIANYAR
}

\author{
Nabila NF${ }^{1}$, Cucu Atikah ${ }^{1}$, Kristiana Maryani ${ }^{1}$ \\ ${ }^{1}$ Program Studi Pendidikan Guru Pendidikan Anak Usia Dini, Fakultas Kependidikan dan Ilmu \\ Pendidikan, Universitas Sultan Ageng Tirtayasa, J1 Ciwaru Raya No 25 Kota Serang \\ Penulis untuk korespondensi/ E-mail: nabilanfero25@gmail.com
}

\begin{abstract}
Abstrak - Pandemi Covid-19 membawa dampak perubahan pada pelaksanaan pendidikan yang sedianya dilakukan secara tatap muka, disesuaikan melalui kegiatan Belajar dari rumah (BDR). Pelaksanaan BDR yang tidak direncanakan sebelumnya oleh pendidik, peserta didik dan orang tua mendatangkan berbagai tantangan. Oleh karena itu penelitian ini dilakukan untuk mengetahui penerapan dan tahapan pembelajaran dalam jaringan selama pandemic Covid-19 di kampong Cianyar Desa Ciuyah. Subjek penelitian ini adalah guru, orang tua dan anak usia 5-6 tahun berjumlah 25 orang. Data primer diperoleh melalui wawancara yang mendalam dengan subjek penelitian yang dilanjutkan dengan observasi dan dokumentasi sebagai proses awal analisis. Selanjutnya, dianalisis dengan mereduksi dan mengklsifikasikan data. Setiap analisis dinarasikan secara deskriptif dan disimpulkan sesuai dengan pertanyaan rumusan masalahnya. Berdasarkan hasil identifikasi, penerapan pembelajaran dalam jaringan selama pandemi Covid-19 di kampong Cianyar Desa Ciuyah dilakukan melaui tahapan tujuan, perencanaan, materi, pelaksanaan, dan evaluasi. Pembelajaran dalam jaringan menggunakan aplikasi WhatsApp, pelaksanaan pembelajaran daring yang dilaksanakan meliputi kegiatan pembukaan, kegiatan inti, teknik tampilan dan sharing ilmu. Dan yang terakhir tahapan evaluasi pembelajaran daring yang berisi penilaian terhadap hasil kegiatan anak yang dikirim melalui video dan foto.
\end{abstract}

Kata Kunci : Anak Usia Dini, Covid-19, Belajar Dari Rumah

\begin{abstract}
The Covid-19 pandemic has brought about changes in the implementation of education which was originally carried out face-to-face, adjusted through Learning from Home (BDR) activities. The implementation of BDR that was not planned in advance by educators, students and parents has various challenges. Therefore, this study was conducted to determine the application and stages of online learning during the Covid-19 pandemic in Cianyar village, Ciuyah Village. The subjects of this study were teachers, parents and children aged 5-6 years opening 25 people. Primary data were obtained through in-depth interviews with research subjects followed by observation and documentation as the initial process of analysis. Furthermore, it is analyzed by reducing and classifying the data. Each analysis is narrated descriptively and safely according to the formulation of the problem. Results Based on the implementation of online learning during the Covid-19 pandemic in Cianyar village, Ciuyah Village, it was carried out through the stages of objectives, planning, materials, and evaluation. Learning in the network using the WhatsApp application, the implementation of bold learning that is carried out includes opening activities, core activities, display techniques and sharing knowledge. And the last is a bold learning evaluation that contains the results of children's activities sent through videos and photos.
\end{abstract}

Keywords: Early Childhood, Covid-19, Learning From Home 


\section{PENDAHULUAN}

$\mathrm{P}$ embelajaran anak usia dini adalah kegiatan pembelajaran yang ditujukan pada anak usia dini yang memberikan pengalaman belajar melalui bermain, mencari pengetahuan sesuai kemampuan dan memberikan pembendaharaan kata pada anak.Pembelajaran pada saat pandemi covid19 saat ini memberikan dampak dalam bidang apapun termasuk pendidikan. Salah satunya dalam bidang pendidikan anak usia dini yang mengharuskan guru untuk melakukan pembelajaran daring.

Proses pembelajaran di sekolah merupakan alat kebijakan publik terbaik sebagai upaya peningkatan pengetahuan dan skill. Selain itu banyak siswa menganggap bahwa sekolah adalah kegiatan yang sangat menyenangkan, mereka bisa berinteraksi satu sama lain dan sekolah dapat meningkatkan keterampilan sosial dan kesadaran kelas sosial siswa. Sekolah secara keseluruhan adalah media interaksi antar siswa dan guru untuk meningkatkan kemampuan integensi, skill dan rasa kasih sayang diantara mereka. Tetapi sekarang kegiatan yang bernama sekolah berhenti dengan tiba-tiba karena gangguan Covid-19.

Wulandari \& Purwanta (2020) berpendapat bahwa memang tak terpungkiri salah satu nya adalah kebijakan belajar online, atau dalam jaringan (daring) untuk seluruh siswa/i hingga mahasiswa/i karena adanya pembatasan sosial. Menteri Pendidikan dan Kebudayaan Republik Indonesia mengeluarkan Surat Edaran Nomor 4 Tahun 2020 Tentang Pelaksanaan Kebijakan Pendidikan Dalam Masa Darurat Penyebaran Coronavirus Disease (Covid-19) poin ke 2 yaitu proses belajar dari rumah dilaksanakan dengan ketentuan sebagai berikut :

a. Belajar dari rumah melalui pembelajaran daring/jarak jauh dilaksanakan untuk memberikan pengalaman belajar yang bermakna bagi siswa, tanpa terbebani tuntutan menuntaskan seluruh capaian kurikulum untuk kenaikan kelas maupun kelulusan;

b. Belajar dari rumah dapat difokuskan pada pendidikan kecakapan hidup antara lain mengenai pandemic Covid-19;

c. Aktivitas dan tugas pembelajaran belajar dari rumah dapat bervariasi antarsiswa, sesuai minat dan kondisi masing-masng, termasuk mempertimbangkan kesenjangan akses/fasilitas belajar dirumah; d. Bukti atau produk aktivitas belajar dari rumah diberi umpan balik yang bersifat kualitatif fan berguna dari guru, tanpa diharuskan memberi skor/nilai kuantitatif;

Kementerian Pendidikan Indonesia mengeluarkan Surat Edaran (SE) Nomor 15 Tahun 2020 tentang Pedoman Penyelenggaraan Belajar Dari Rumah Dalam Masa Darurat Penyebaran Coronavirus Disease (Covid-19) (Kementerian Pendidikan, 2020). Berdasarkan SE tersebut kegiatan belajar mengajar di sekolah baik jenjang Pendidikan Anak Usia Dini (PAUD), Pendidikan Sekolah Dasar, sekolah menengah pertama, sekolah menengah atas dan perguruan tinggi memberlakukan pembelajaran di rumah dengan sistem dalam jaringan (daring). Pembelajaran PAUD sebagai stimulasi perkembangan dan persiapan dalam menempuh tingkat pendidikan selanjutnya.

Kegiatan pembelajaran PAUD biasa dilakukan dengan tatap muka dan interaksi langsung antara guru dan peserta didik, saat ini dilakukan dengan pembelajaran di rumah masing-masing peserta didik. Sujiono (2009: 30) menyatakan bahwa pendidikan anak usia dini meliputi segala hal baik upaya maupun tindakan yang berikan oleh pendidik dan orang tua untuk memberikan stimulasi, bimbingan, perawatan dan pengasuhan pada anak usia dini sehingga tercipta suasana dan lingkungan yang memungkin anak dapat mengeksplorasi pengalaman, pengetahuan dan pemahaman terhadap pengalaman belajar yang telah diperoleh anak dari lingkungan, dengan cara mengamati, meniru, bereksperimen secara berulangulang dan melibatkan semua potensi dan kecerdasan anak (Sujiono, 2012).

Pada kenyataanya Anak Usia Dini (AUD) di kampung Cianyar mengalami kejenuhan dalam belajar akan memperoleh ketidak majuan dalam hasil belajar. Diperlukan pendorong untuk menggerakkan Pendidikan Anak Usia Dini (PAUD) yang berusia $5-6$ tahun, agar semangat belajar dapat dimiliki dengan meningkatkan motivasi belajar siswa, guru dan juga dapat mencapai hasil yang diharapkan sesuai amanat kurikulum. Motivasi belajar yaitu sebuah penggerak atau pendorong yang membuat seseorang akan tertarik kepada belajar sehingga akan belajar secara terus-menerus.

Berdasarkan latar belakang di atas maka peneliti mengambil judul penelitian "Pelaksanaan Belajar Dari Rumah Selama COVID 19 Pada Anak Usia 56 Tahun Di Kampung Cianyar Desa Ciuyah" 


\section{METODE PENELITIAN}

Pada penelitian ini metode penelitian yang digunakan peneliti adalah penelitian deskriptif kualitatif. Peneliti menggunakan metode studi kasus. Adapun data yang diperoleh peneliti ini berasal dari observasi, wawancara, catatan lapangan dan dokumentasi. Pada penulisan laporan, peneliti menganalisa data sesuai dengan pembelajaran anak usia 5-6 Tahun di Kampung Cianyar Desa Ciuyah Kecamatan Sajira Kabupaten Lebak-Banten. Peneliti berusaha menelusuri dan menggali informasi mengenai kedisiplinan dalam pembelajaran anak usia 5-6 tahun. Hasil penelitian kemudian dianalisis oleh peneliti dan dijabarkan dalam bentuk narasi.

\section{HASIL DAN PEMBAHASAN}

Pelaksanaan pembelajaran di rumah sudah berjalan ditengah pandemik COVID-19. Proses pembelajaran dilakukan secara daring, guru memberikan kebebasan kepada anak untuk melaksanakan proses pemebelajaran dimana saja asalkan kondusif dan nyaman. Hal ini sudah sesuai dengan ketentuan Surat Edaran Nomor 4 Tahun 2020 Tentang Pelaksanaan Kebijakan Pendidikan Dalam Masa Darurat Penyebaran Coronavirus Disease (Covid-19) poin ke 2 yaitu proses belajar dari rumah dilaksanakan dengan ketentuan sebagai berikut: Belajar dari rumah melalui pembelajaran daring/jarak jauh dilaksanakan untuk memberikan pengalaman belajar yang bermakna bagi anak, tanpa terbebani tuntutan menuntaskan seluruh capaian kurikulum untuk kenaikan kelas maupun kelulusan; Aktivitas dan tugas pembeljaran belajar dari rumah dapat bervariasi antaranak, sesuai minat dan kondisi masing-masng, termasuk mempertimbangkan kesenjangan akses/fasilitas belajar dirumah; Bukti atau prosuk aktivitas belajar dari rumah diberi umpan balik yang bersifat kualitatif dan berguna dari guru, tanpa diharuskan memberi skor/nilai kuantitatif.

Pelaksanaan pembelajaran guru telah mempersiapkan diri untuk mengajar dengan tepat waktu dalam memulai pembelajaran, guru telah mempersiapkan materi yang akan dipelajari oleh anak, dan dalam proses pembelajaran guru menggunakan metode pembelajaran daring. Hal sudah sesuai dengan teori perencaan pembelajaran bahwa guru membuat perencanaan pembelajaran untuk mencapai tujuan pembelajaran. Menurut Ibrahim secara garis besar perencaan pembelajaran mencakup kegiatan merumuskan tujuan apa yang dicapai oleh suatau kegiatan pembelajaran, cara apa yang digunakan, materi bahan apa yang akan disampaikan, bagaimana cara menyampaikannya, serta alat atau media apa yang diperlukan (Djoehaeni, 2010).

Proses pembelajaran orang tua murid merasa kewalahan dengan keterbatasan sarana dan prasaran yang dimiliki di rumah, selain itu dengan harus membimbing anaknya menambah pekerjaan orang tua murid. Sehingga masih ada beberapa anak yang tidak dapat memenuhi subtema pembelajaran yang diberikan oleh guru.

Selain itu, kendala yang dialami saat pembelajaran di rumah berlangsung yaitu orang tua anak yang tidak memiliki handphone sehingg harus bergabung dengan tetangga, kendala jaringan saat proses pembelajaran berlangsung, kendala orang tua yang sibuk bekerja seperti bertani sehingga tidak dapat mendampingi anak dengan maksimal, guru tidak dapat menjelaskan materi dan melihat perkembangan anak secara maksimal, kurang pemahaman orang tua terhadap arahan yang diberikan oleh guru yang menyebabkan anak ketinggalan, dan keterbatasan sarana prasarana di rumah menjadi kendala bagi kegiatan pembelajaran di rumah

Hasil pengamatan, wawancara dan dokumentasi menunjukkan bahwa pembelajaran di rumah anak usia 5-6 tahun di Kampung Cianyar Desa Ciuyah Kecamatan Sajira Kabupaten Lebak berlangsung cukup baik. Walaupun belajar secara di rumah kemampuan motorik dan kognitif anak anak cukup baik. Hal ini diperkuat dengan hasil jawaban wawancara guru (CWG04).

Untuk nilai - nilai moral dan agama dalam proses pembelajaran secara di rumah tidak dapat dilihat secara jelas, karena guru tidak dapat mengamati secara leluasa seperti pembelajaran tatap muka di sekolah. Hal ini diperkuat oleh jawaban wawancara dengan guru (CWG05). Selain itu, banyak kendala yang di alami oleh guru dan orang tua murid yang disebabkan oleh kurangnya sarana dan prasarana di rumah.

Hal ini juga diperkuat oleh jawaban wawancara dengan guru kelas dan orang tua murid (CWG01, CWO03). Ada beberapa orang tua murid yang kewalahan dalam memberikan permainan edukatif untuk anaknya, walaupun sudah diberi arahan oleh guru (CWO02), hal ini juga bisa dikarenakan sarana dan prasarana yang kurang memadai di rumah. Hasil wawancara dan dokumentasi menunjukkan bahwa pembelajaran di rumah anak usia 5-6 tahun 
di kampung Cianyar desa Ciuyah kecamatan Sajira kabupaten Lebak memiliki kendala (CWG01, 04, 05), (CWO01,CW03), (CL02, CL03, CL06) (CD6, CD09). Pada proses pembelajaran di rumah memiliki kendala yaitu seperti kurangnya sarana dan prasarana yang berbedan dengan sekolah, dan keterbatasannya pemahaman orang tua akan arahan guru.

\section{SIMPULAN DAN SARAN}

Berdasarkan hasil penelitian mengenai "Pelaksanaan Belajar Dari Rumah Selama COVID19 Pada Anak Usia 5-6 Tahun Di Kampung Cianyar Desa Ciuyah", dapat diambil beberapa kesimpulan sebagai berikut:

Pertama, pelaksanaan pembelajaran di rumah anak usia 5-6 tahun di kampung cianyar desa ciuyah kecamatan sajira kabupaten lebak tidak seefektif ketika belajar di dalam kelas hal ini terlihat ketika anak belajar menggunakan hanphone anak harus di beri semangat oleh orang tua terlebih dahulu sebelum pembelajaran dimulai. Pada saat pembelajaran berlangsung guru memberikan kebebasan kepada anak untuk melaksanakan proses pembelajaran dimana saja asal kondusif dan nyaman.

Kedua, kendala pelaksanaan pembelajaran di rumah anak usia 5-6 tahun di kampung cianyar desa ciuyah kecamatan sajira kabupaten lebak yaitu saat proses pembelajaran orang tua murid mengalami kewalahan dengan keterbatasan sarana dan prasarana yang di miliki di rumah, selain itu ada orang tua anak yang tidak memiliki handphone sehingga harus bergabung dengan tetangga, kendala jaringan saat proses pembelajaran berlangsung, kendala orang tua yang sibuk bekerja sehingga tidak dapat mendampingi anak dengan maksimal, dan guru tidak dapat menjelaskan materi dan melihat perkembangan anak secara maksimal.

Ketiga, dampak pelaksanaan pembelajaran di rumah anak usia 5-6 tahun di kampung cianyar desa ciuyah kecamatan sajira kabupaten lebak Walaupun dalam proses pembelajaran di rumah berjalan dengan baik, namun tetap saja memiliki dampak bagi anak anak. Di karenakan harus belajar di rumah menyebabkan anak-anak tidak bisa bertemu dan bermain dengan teman seusianya hal ini menyebabkan ada beberapa anak yang kurang bersemangat dengan pembelajaran di rumah dan anak tidak bisa bersosialisasi dengan teman satu sekolahnya.
Berdasarkan simpulan di atas maka saran yang dapat diberikan kepada orang tua diharapkan bisa mendampingi anak dan memberikan sarana kepada anak ketika anak belajar sehingga anak bisa mengikuti pembelajaran yang diberikan guru. Sementara saran untuk guru adalah agar guru bisa memberikan materi yang singkat dan jelas sehingga anak bisa mengikuti pembelajaran dengan maksimal.

\section{DAFTAR PUSTAKA}

Abdul, W.S. (2008). Pengantar Analisis Kebijakan Publik. Malang: Universitas Muhamadiyah.

Abdullah, S. (1987). Study Implementasi Latar Belakang Konsep Pendekatan dan Relevansinya dalam Pembangunan. Ujung Pandang: Persadi.

Ahmadi, A. (2013). Psikologi Belajar. Jakarta: Rieneka Cipta.

Arifa, F.N (2020). Tantangan Pelaksanaan Kebijakan Belajar dari Rumah. Info Singkat, 13-18.

Aziz, H.A. (2016). Karakter Guru Profesional. Jakarta: Al-Mawardi Prima.

Barnes, M., \& Garth R, J. (2008). Upper Motor Neurone Syndrom and Spasticty 2nd ed New York. Jakarta: Kedokteran EGC.

Depdiknas. (2002). Pendekatan Kontekstual (Contextual Teaching And Learning). Jakarta: Depdiknas.

Djamarah, S. (2008). Psikologi Belajar. Jakarta: Rineka Cipta.

Djoehaeni. (2010). Komponen Perencanaan Pembelajaran. Bandung: Tidak di terbitkan.

Fadlillah, M. dan Khorida, L.M. 2013. Pendidikan Karakter Anak Usia Dini. Yogyakarta: ArRuzz Media.

Fadillah, M., \& KHorida, L. (2013). Pendidikan Karakter Anak Usia Dini. Yogjakarta: Ar-Ruzz Media.

Hartani, A. (2011). Managemen Pendidikan. Yogyakarta: Laksbang Pressindo.

Hartati, S. (2015). Perkembangan Belajar Pada Anak Usia Dini. Jakarta: Departemen Pendidikan Nasional.

Imron, A. (2011). Manajemen Peserta Didik Berbasis Sekolah. Jakarta: Bumi Aksara.

Johnson, E. (2008). Contextual Teaching Learning: Menjadikan Kegiatan Belajar Mengajar Mengasyikan dan Bermakna. Bandung: Mizan Learning Center.

Megawangi, R. (2007). Pendidikan Karakter, Jakarta: Indonesia Heritage Foundation 
Moleong, L. (2007). Metode Penelitian Kualitatif. Bandung: PT Remaja Rosdakarya Offset.

Mona, N. (2020). Konsep Isolasi Dalam Jaringan Sosial Untuk Meminimalisasi Efek Contagious (Kasus Penyebaran Virus Corona Di Indonesia). Sosial Humaniora Terapan Universitas Indonesia, 2.

Mulyasa. (2014). Managemen PAUD. Bandung: Rosdakarya.

Muslich, M. (2008). KTSP Pembelajaran Berbasis Kompetensi Dan Kontekstual. Jakarta: Bumi Aksara.

Nailufar, N.N. (2018). Ada Tempat Sampah. Pengunjung Kota Tua Tetap Buang Sampah Sembarangan. Kompas. [Online]. Tersedia: http://megapolitan.kompas.com/read/2018/01/0 1/19195941/ada-tempat sampah-pengunjungkota-tua-tetap-buang-sampah-sembarangan. [9 Februari 2018].

Nurhadi. (2003). Pendekatan Kontekstual (Contextual Teaching and Learning). Jakarta: Depdiknas.

Nurmasyitah, M.S. (2017). Peran Guru Dalam Pelaksanaan Manajemen Kelas Di Gugus Bungong Seulanga kecamatan Syiah Kuala kota Banda Aceh. [Online], Vol.2, No.1.

Qalamuna. (2020). Urgensi Pembentukan Aturan Terkait Pencegahan Covid-19 di Indonesia. Jurnal Pendidikan, Sosial dan Agama. Vol. 12 No. 1.

Rahmasari, H.D. (2015). Proses Pembelajaran Anak Usia Dini.

Rusdinal. (2015). Pengelolaan Kelas di Taman Kanak-kanak. Jakarta: Diknas.

Robert C.P, Karen M.L, Brook E.S. et al. (2006). The Teacher Belief Q-Sort: A measure of teachers' priorities in relation to disciplinary practices, teaching practices, and beliefs about children. [Online], Vol.44, No.2.

Sagala, S. (2013). Konsep dan makna pembelajaran. Bandung: Alfabeta.

Sugiyono. (2014). Metode Penelitian Pendekatan Kuantitatif, Kualitatif dan $R \& D$. Bandung: Alfabeta.

Sujana, N. (2010). Dasar-dasar Proses Belajar. Bandung: Sinar Baru.
Sugiyono. (2014). Metode Penelitian Kuantitatif, Kualitatif, Dan, $R \& D$. Bandung: Alfabeta.

Sujiono, Y.N. (2009). Konsep Dasar Pendidikan Anak Usia Dini. Jakarta: Jaya Cemerlang.

Sujiono, Y. (2009). Konsep Dasar Pendidikan Anak Usia Dini. Jakarta: Indeks.

Suprijono, A. (2010). Comparative Learning. Yogyakarta: Pustaka Media.

Suprihatinungrum, Jl. (2014). Guru profesional: Pedoman Kinerja, Kualifikasi, \& Kompetensi Guru. Yogyakarta: Ar-Ruzz Media.

Sujiono, B. \& Sujiono, Y.N. (2005). Mencerdaskan Perilaku Anak Usia Dini. Jakarta: PT. Elex Media Komputindo.

Suprihatinungrum, J. (2014). Guru profesional: Pedoman Kinerja, Kualifikasi, \& Kompetensi Guru. Yogyakarta: Ar-Ruzz Media.

Thobroni, M. (2015). Belajar \& pembelajaran: Teori dan Praktik. Yogyakarta: Ar-Ruzz Media.

Thobroni, M., \& Mustofa, A. (2013). Belajar dan Pembelajaran. Yogyakarta: Ar-Ruzz Media.

World Health Organization. (2020). https://www.who.int/indonesia/news/novelcoronavirus/qa-for-public. -: -.

Wulandari, A. (2020). Kemendikbud Terbitkan Pedoman Penyelenggaraan Belajar dari Rumah. Jakarta: Oke News.

Yuliana. (2020). Respirologi Indonesia. Wellness and Healty Magazine, 187-182

http://www.paudni.kemdikbud.go.id/wpcontent/uploads/2012/02/15.-JuknisPenyelenggaraan-Pendidikan-Karakter.p (2010). Strategi Belajar Mengajar. Jakarta: Rineka Cipta.

(2003). Pendekatan Kontekstual (Contxtual Teaching And Learning). Jakarta: Depdiknas.

(2003). Pembelajaran Kontekstual (Contextual Teaching And Learning/CTL) Dan Penerapannya dalam KBK. Malang: Universitas Negeri Malang.

(2010). Konsep Dasar Pendidikan Anak Usia Dini. Jakarta: Jaya Cemerlang. 